\title{
Pengaruh Kemampuan Pemecahan Masalah dan Kecerdasan Emosional Terhadap Kemampuan Berpikir Kreatif Siswa
}

\author{
Yenti ${ }^{1}$, Suaedi$^{2}$, Ma'rufi $^{3}$, \\ SMK Negeri 4 Luwu $^{1}$, Universitas Cokroaminoto Palopo ${ }^{2,3}$ \\ Email: antiy1152@gmail.com², suaedif@gmail.com², marufi@uncp.ac.id³,
}

\begin{abstract}
Abstrak. Penelitian ini merupakan penelitian kuantitatif ex post facto dengan sampel sebanyak 60 orang siswa kelas X SMKN 4 Luwu yang diambil secara random sampling. Variabel penelitian terdiri dari kemampuan pemecahan masalah dan kecerdasan emosional sebagai variabel bebas dan kemampuan berpikir kreatif sebagai variabel terikat. Instrumen penelitian terdiri dari tes untuk mengetahui kemampuan pemecahan masalah dan kemampuan berpikir kreatif serta angket kecerdasan emosional. Analisis data menggunakan analisis regresi linier sederhana untuk mengetahui pengaruh variabel bebas secara parsial dan analisis regresi linier berganda untuk mengetahui pengaruh secara simultan. Hasil penelitian menunjukkan bahwa terdapat pengaruh kemampuan pemecahan masalah terhadap kemampuan berpikir kreatif sebesar 26,8\%. Terdapat pengaruh kecerdasan emosional terhadap kemampuan berpikir kreatif sebesar 10,1\%. Terdapat pengaruh secara bersama-sama kemampuan pemecahan masalah dan kecerdasan emosional terhadap kemampuan berpikir kreatif sebesar 28,9\%. Dengan demikian dapat disimpulkan bahwa semakin tinggi kecerdasan emosional yang dimiliki siswa dalam memecahkan masalah maka semakin tinggi kemampuan berpikir kreatif siswa.
\end{abstract}

\section{Kata Kunci: Kemampuan Pemecahan Masalah, Kecerdasan Emosional, Kemampuan Berpikir Kreatif}

\begin{abstract}
This research is an ex post facto quantitative research with a sample of 60 students of class X SMKN 4 Luwu taken by random sampling. The research variables are problem-solving abilities and emotional intelligence as independent variables and creative thinking skills as dependent variables. The research instrument is a test to determine problem solving skills and creative thinking skills as well as emotional intelligence questionnaires. Data analysis used simple linear regression analysis to determine the effect of the independent variables partially and multiple linear regression analysis to determine the effect simultaneously. The results showed that there was an effect of problem-solving ability on creative thinking ability of $26.8 \%$. There is an influence of emotional intelligence on the ability to think creatively by $10.1 \%$. There is a joint influence of problem-solving ability and emotional intelligence on creative thinking ability of $28.9 \%$. Thus, it can be concluded that the higher the emotional intelligence of students in solving problems, the higher the students' creative thinking abilities
\end{abstract}

Keywords: problem-solving, emotional intelegent, creative thinking

\section{A. Pendahuluan}

Kreativitas dalam matematika lebih pada kemampuan berpikir kreatif. Karena secara umum sebagian besar aktivitas yang dilakukan seseorang yang belajar matematika adalah berpikir. berpikir kreatif dalam matematika merupakan kombinasi berpikir logis dan berpikir divergen yang didasarkan intuisi tetapi dalam kesadaran yang memperhatikan fleksibilitas, kefasihan dan kebaruan (Pehkonen, 1999). Menurut Soeyono (2013) bahwa berpikir kreatif adalah proses berpikir divergen untuk menemukan solusi yang baru yang menekankan pada aspek kelancaran (fluently), keluwesan (flexibility), keaslian (originality), elaborasi (elaboration)

Berpikir kreatif memerlukan pengetahuan/pengalaman awal yang cukup agar memiliki beberapa kemungkinan strategi atau ide yang dapat dimunculkan. Berpikir kreatif juga bukan merupakan faktor keturunan, sehingga dapat dikembangkan dan dapat diajarkan dengan metode maupun strategi pembelajaran tertentu yang dapat mendukung berkembangnya kemampuan 
berpikir kreatif. Oleh karena itu, untuk mengembangkan berpikir siswa diperlukan kemampuan pemecahan masalah sebagai salah satua spek yang perlu dijadikan fokus perhatian.

Pemecahan masalah matematika pada umumnya lebih identik dengan soal-soal yang berbentuk uraian. Hal ini dikarenakan soal yang berbentuk uraian membutuhkan tahapan pemecahan yang bertahap sehingga kesimpulan yang didapatkan jelas dan sistematis. Pentingnya kemampuan pemecahan masalah oleh siswa dalam matematika ditegaskan juga oleh Hakim (Sianipar dan Roida, 2015), yaitu suatu proses untuk peserta didik dimungkinkan memperoleh pengalaman menggunakan pengetahuan serta keterampilan yang sudah dimilikinya untuk diterapkan dalam menyelesaikan soal-soal berbentuk masalah atau soal-soal aplikasi dalam pelajaran matematika.

Polya (Mawaddah dan Hana, 2015) menambahkan empat langkah untuk memecahkan masalah matematika, yaitu (1) mampu memahami masalah; (2) mampu membuat rencana menyelesaikan masalah; (3) mampu melaksanakan rencana pemecahan masalah; (4) mampu memeriksa kembali. Kemampuan ini sangat dibutuhkan oleh siswa, karena pada dasarnya siswa dituntut untuk berusaha sendiri mencari pemecahan masalah matematika.

Sayangnya, kemampuan pemecahan masalah siswa masih dinilai rendah. Berdasarkan survey International PISA Indonesia selalu berada pada urutan tujuh terbawah dibandingkan negara-negara lainnya. Siswa di Indonesia masih lemah dalam kemampuan pemecahan masalah matematika. Lebih lanjut penyebab dari lemahnya kemampuan siswa dalam memecahkan masalah adalah siswa kurang terbiasa melakukan proses pemecahan masalah dengan benar, yaitu dengan tahapan memahami masalah, merencanakan pemecahan masalah, melaksanakan pemecahan masalah dan mengecek hasil pemecahan masalah.

Lebih lanjut dengan hal tersebut, pada survei PISA, yaitu suatu penilaian secara internasional terhadap keterampilan dan kemampuan siswa usia 15 tahun, yang dilakukan oleh OECD (Organisation for Economic Cooperation and Development) setiap 3 (tiga) tahun sekali tidak berbeda jauh hasilnya dengan survei TIMSS di atas. Dalam survei PISA tahun 2018, untuk kategori matematika, Indonesia berada di peringkat 7 dari bawah (73) dengan skor rata-rata 379. Indonesia berada di atas Arab Saudi yang memiliki skor rata-rata 373. Kemudian untuk peringkat satu, masih diduduki China dengan skor rata-rata 591. Artinya indonesia berada pada pringkat 73 dari 79 negara yang ikut dalam survey. Selain kemampuan pemecahan masalah, faktor lain yang memengaruhi kemampuan berpikir kreatif adalah kecerdasan emsoional.

Berdasarkan penelitian relevan yang terdahulu oleh Eva dan Kusrini (2015), dengan hasil penelitiannya menunjukkan bahwa terdapat hubungan kecederdasan emosional dan berpikir kretaif terhadap prestasi belajar matematika. Kecerdasan emosional merupakan kemampuan siswa dalam mengendalikan emosi dari dalam diri sendiri sehingga dapat menyelesaikan suatu tugas yang dibebankan dengan baik. Berdasarkan pengamatan peneliti, kecerdasan emosional siswa SMK khususnya kelas X SMK Negeri 4 Luwu masih rendah dan labil. Hal ini disebabkan jenjang SMK sederajat merupakan masa peralihan dari tingkat anak-anak menuju dewasa. Siswa masih cenderung egois dan kurang fokus dalam belajar sehingga motivasi belajarnya kurang baik.

Setiap pribadi manusia memiliki potensi dan talenta dalam dirinya, tugas pendidikan yang sejati adalah membantu siswa untuk menemukan dan mengembangkan seoptimal mungkin. Mewujudkan masyarakat yang berkualitas dari segi pendidikan tersebut merupakan tanggung jawab bidang pendidikan, terutama dalam mempersiapkan siswa menjadi manusia yang berkualitas dari segi kecerdasan emotional (EQ).

Berdasarkan uraian tujuan penelitian ini yaitu mengetahui apakah ada pengaruh kemampuan pemecahan masalah matematika dan kecerdasan emosional terhadap kemampuan berpikir kreatif siswa kelas X SMK Negeri 4 Luwu. 


\section{B. Metodologi Penelitian}

Penelitian ini adalah penelitian ex post facto yang bertujuan untuk mengkaji pengaruh kemampuan pemecahan masalah dan kecerdasan emosional terhadap kemampuan berpikir kreatif siswa kelas X SMK Negeri 4 Luwu. Penelitian ini dilaksanakan di SMK Negeri 4 Luwu yang terletak di Jalan Poros Palopo-Masamba Km 14 Karetan Kecamatan Walenrang Kabupaten Luwu, Sulawesi Selatan.

Populasi dalam penelitian ini keseluruan siswa kelas X SMK Negeri 4 Luwu yang berjumlah 137 siswa. Sampel penelitian ini sebanyak 60 siswa. Teknik pemilihan sampel yang digunakan yaitu teknik random sampling, yaitu mengambil sampel secara acak. Data dalam penelitian ini diperoleh dari hasil tes dan pengisian kuesioner oleh siswa. intrumen yang digunakan dalam penelitian yaitu tes kemampuan pemecahan masalah, angket kecerdasan emosional, dan tes kemampuan berpikir kreatif.

Data yang diperoleh dalam penelitian ini dianalisis secara statistika deskriptif untuk melihat gambaran setiap variabel dan statistika inferensial untuk menguji hipotesis. Uji hipotesis yang digunakan adalah regresi linear sederhana (uji hipotesis 1 dan 2) dan regresi linear berganda (uji hipotesis 3 ) dengan uji prasyarat yaitu uji normalitas dan linearitas.

\section{Hasil Penelitian dan Pembahasan}

\section{Kemampuan Pemecahan Masalah Matematika Siswa}

Berdasarkan hasil analisis yang dilakukan, diperoleh gambaran kemampuan pemecahan masalah matematika siswa kelas X SMK Negeri 4 Luwu sebagai berikut.

Tabel 1. Statistika deskriptif kemampuan pemecahan masalah matematika siswa kelas X SMK Negeri 4 Luwu

\begin{tabular}{clc}
\hline No & Statistik & Nilai Statistik \\
\hline 1 & Jumlah Sampel & 60,00 \\
2 & Rata-rata & 84,35 \\
3 & Median & 84,09 \\
4 & Standar Deviasi & 6,97 \\
5 & Variansi & 48,69 \\
6 & Rentang & 27,27 \\
7 & Nilai Minimal & 70,45 \\
8 & Nilai Maksimal & 81,63 \\
9 & Nilai Ideal & 100,00 \\
\hline
\end{tabular}

Sumber: Data primer setelah diolah (2021)

Berdasarkan Tabel, terlihat bahwa rata-rata pemecahan masalah siswa kelas X SMK Negeri 4 Luwu sebesar 84,35, dengan median sebesar 84,09, nilai tertinggi sebesar 81,63, nilai terendah sebesar 70,45, dan nilai maksimun 100.

Data pemecahan masalah siswa selanjutnya dikategorisasi menjadi lima kelompok. maka diperoleh distributif frekuensi kemampuan pemecahan masalah matematika siswa kelas $\mathrm{X}$ SMK Negeri 4 Luwu sebagai berikut.

Tabel 2. Distributif frekuensi kemampuan pemecahan masalah matematika siswa kelas X SMK Negeri 4 Luwu

\begin{tabular}{ccccc}
\hline No & Interval & Frekuensi & Persentase $(\%)$ & Kategori \\
\hline 1 & $0 \leq x<20$ & 0 & 0,00 & Sangat rendah \\
2 & $20 \leq x<40$ & 0 & 0,00 & Rendah \\
3 & $40 \leq x<60$ & 0 & 0,00 & Sedang \\
4 & $60 \leq x<80$ & 16 & 26,67 & Tinggi \\
5 & $80 \leq x \leq 100$ & 44 & 73,33 & Sangat Tinggi \\
\hline
\end{tabular}


Sumber: Data primer setelah diolah (2021)

Berdasarkan tabel, diperoleh dari 60 siswa kelas X SMK Negeri 4 Luwu, $0(0,00 \%)$ siswa yang memiliki kemampuan pemecahan masalah matematika sangat rendah, rendah dan sedang, $16(26,67 \%)$ siswa yang memiliki kemampuan pemecahan masalah matematika tinggi dan 44 $(73,33 \%)$ siswa yang memiliki kemampuan pemecahan masalah matematika sangat tinggi.

\section{Keceerdasan Emosional Siswa}

Berdasarkan hasil analisis yang dilakukan, diperoleh gambaran kecerdasan emosional siswa kelas X SMK Negeri 4 Luwu sebagai berikut.

Tabel 3. Statistika deskriptif kecerdasan emosional siswa kelas X SMK Negeri 4 Luwu

\begin{tabular}{|c|c|c|}
\hline No & Variabel & Nilai Statistik \\
\hline 1 & Jumlah Sampel & 60,00 \\
\hline 2 & Rata-rata & 74,77 \\
\hline 3 & Median & 75,00 \\
\hline 4 & Standar Deviasi & 3,91 \\
\hline 5 & Variansi & 15,31 \\
\hline 6 & Rentang & 16,84 \\
\hline 7 & Nilai Minimal & 64,80 \\
\hline 8 & Nilai Maksimal & 81,63 \\
\hline 9 & Nilai Ideal & 100,00 \\
\hline
\end{tabular}

Sumber: Data primer setelah diolah (2021)

Berdasarkan Tabel, terlihat bahwa rata-rata kecerdasan emosional siswa siswa kelas $\mathrm{X}$ SMK Negeri 4 Luwu sebesar 74,77, dengan median sebesar 75,00, nilai tertinggi sebesar 81,63, nilai terendah sebesar 64,80, dan nilai maksimun 100 .

Data kecerdasan emosional siswa selanjutnya dikategorisasi menjadi lima kelompok. Berdasarkan pengkategorian tersebut, maka diperoleh distributif frekuensi kecerdasan emosional siswa siswa kelas X SMK Negeri 4 Luwu sebagai berikut.

Tabel 4. Distributif frekuensi kecerdasan emosional siswa siswa kelas X SMK Negeri 4 Luwu

\begin{tabular}{ccccc}
\hline No & Interval & Frekuensi & Persentase (\%) & Kategori \\
\hline 1 & $\mathrm{x} \geq 80,63$ & 1 & 1,67 & Sangat Tinggi \\
2 & $76,72 \leq \mathrm{x}<80,63$ & 22 & 36,66 & Tinggi \\
3 & $72,81 \leq \mathrm{x}<76,72$ & 21 & 35,00 & Sedang \\
4 & $68,90 \leq \mathrm{x}<72,81$ & 9 & 15,00 & Rendah \\
5 & $68,90 \geq \mathrm{x}$ & 7 & 11,67 & Sangat Rendah \\
\hline & Jumlah & 60 & 100,00 & \\
\hline
\end{tabular}

Sumber: Data primer setelah diolah (2021)

Berdasarkan tabel, dari 60 siswa kelas X SMK Negeri 4 Luwu, 1 (1,67\%) siswa yang memiliki kecerdasan emosional sangat tinggi, $22(36,66 \%)$ siswa yang memiliki kecerdasan emosional tinggi, $21(35,00 \%)$ siswa yang memiliki kecerdasan emosional sedang, $9(15,00 \%)$ siswa yang memiliki kecerdasan emosional rendah, dan 7 11,67\%) siswa yang memiliki kecerdasan emosional sangat rendah.

\section{Kemampuan Berpikir Kreatif Siswa}

Berdasarkan hasil analisis yang dilakukan, diperoleh gambaran kemampuan berpikir kreatif siswa kelas X SMK Negeri 4 Luwu sebagai berikut. 
Tabel 5. Statistika deskriptif kemampuan kemampuan berpikir kreatif siswa kelas $\mathrm{X}$ SMK Negeri 4 Luwu

\begin{tabular}{|c|c|c|}
\hline No & Variabel & Nilai Statistik \\
\hline 1 & Jumlah Sampel & 60,00 \\
\hline 2 & Rata-rata & 72,66 \\
\hline 3 & Median & 72,91 \\
\hline 4 & Standar Deviasi & 11,23 \\
\hline 5 & Variansi & 126,11 \\
\hline 6 & Rentang & 37,50 \\
\hline 7 & Nilai Minimal & 50,00 \\
\hline 8 & Nilai Maksimal & 87,50 \\
\hline 9 & Nilai Ideal & 100,00 \\
\hline
\end{tabular}

Sumber: Data primer setelah diolah (2021)

Berdasarkan Tabel, terlihat bahwa rata-rata kemampuan berpikir kreatif siswa kelas $\mathrm{X}$ SMK Negeri 4 Luwu sebesar 72,66, dengan median sebesar 72,91. nilai tertinggi sebesar 87,50, nilai terendah sebesar 50,00, dan nilai maksimun 100,00.

Data kemampuan berpikir kreatif siswa selanjutnya dikategorisasi menjadi lima kelompok. Berdasarkan pengkategorian tersebut, maka diperoleh distributif frekuensi kemampuan berpikir kreatif siswa kelas X SMK Negeri 4 Luwu sebagai berikut.

Tabel 6. Distributif frekuensi kemampuan berpikir kreatif siswa kelas X SMK Negeri 4 Luwu

\begin{tabular}{ccccc}
\hline No & Interval & Frekuensi & Persentase $(\%)$ & Kategori \\
\hline 1 & $85 \leq x \leq 100$ & 12 & 20,00 & Sangat kreatif \\
2 & $75 \leq x<85$ & 14 & 23,33 & Kreatif \\
3 & $65 \leq x<75$ & 15 & 25,00 & Cukup kreatif \\
4 & $55 \leq x<65$ & 13 & 21,67 & Kurang kreatif \\
5 & $30 \leq x<55$ & 6 & 10,00 & Sangat kurang kreatif \\
6 & $0 \leq x<30$ & 0 & 0,00 & Tidak kreatif \\
\hline & Jumlah & 60 & 100,00 & \\
\hline
\end{tabular}

Sumber: Data primer setelah diolah (2021)

Berdasarkan tabel, dari 60 siswa kelas X SMK Negeri 4 Luwu, 12 (20,00\%) siswa yang memiliki kemampuan berpikir kreatif berkategori sangat kreatif, $14(23,33 \%)$ siswa yang memiliki kemampuan berpikir kreatif berkategori kreatif, $15(25,00 \%)$ siswa yang memiliki kemampuan berpikir kreatif berkategori cukup kreatif, $13(21,67 \%)$ siswa yang memiliki kemampuan berpikir kreatif berkategori kurang kreatif, 6 (10,00\%) siswa yang memiliki kemampuan berpikir kreatif berkategori sangat kurang kreatif dan $0(0,00 \%)$ siswa yang memiliki kemampuan berpikir kreatif berkategori tidak kreatif.

\section{Hasil uji hipotesis}

Hasil uji normalitas diperoleh nilai probabilitas data kemampuan pemecahan masalah matematika siswa sebesar $0,200>0,05$ artinya data kemampuan pemecahan masalah matematika berdistribusi normal, nilai signifikan data kecerdasan emosional sebesar 0,062 > 0,05 artinya data kecerdasan emosional berdistribusi normal, dan nilai signifikan data kemampuan berpikir kreatif siswa sebesar 0,178 $>0,05$ artinya data kemampuan berpikir kreatif siswa berdistribusi normal.

Hasil uji linearitas diperoleh sig. deviation from linearity kemampuan pemecahan masalah terhadap kemampuan berpikir kreatif sebesar 0,642>0,05 artinya ada hubungan yang linear secara signifikan kemampuan pemecahan masalah siswa dan kemampuan berpikir kreatif siswa, dan nilai sig. deviation from linearity kecerdasan emosional terhadap kemampuan 
berpikir kreatif sebesar $0,118>0,05$ artinya ada hubungan yang linear secara signifikan kecerdasan emosional dan kemampuan berpikir kreatif siswa.

Hasil analisis uji hipotesis 1, 2 dan 3 diperoleh hasil sebgai berikut.

Tabel 7. Hasil uji hipotesis.

\begin{tabular}{lclc}
\hline Hipotesis & R Square & Persamaan Regresi & Nilai Probailitas \\
\hline Hipotesis 1 & 0,268 & $\mathrm{Y}=1,429+0,833 \mathrm{X}_{1}$ & $0,000^{\mathrm{b}}$ \\
Hipotesis 2 & 0,101 & $\mathrm{Y}=3,336+0,914 \mathrm{X}_{2}$ & $0,013^{\mathrm{b}}$ \\
Hipotesis 3 & 0,289 & $\mathrm{Y}=-24,663+0,744 \mathrm{X}_{1}+0,448 \mathrm{X}_{2}$ & $0,000^{\mathrm{b}}$ \\
\hline
\end{tabular}

Sumber: Data primer setelah diolah (2021)

Berdasarkan tabel terlihat, nilai probabilitas hipotesis 1 sebesar $0,000<0,05$, yang berarti $\mathrm{H}_{0}$ ditolak dan $\mathrm{H}_{1}$ diterima sehingga dapat disimpulkan terdapat pengaruh kemampuan pemecahan masalah matematika terhadap kemampuan berpikir kreatif siswa kelas X SMK Negeri 4 Luwu, dengan kontribusi pengaruh sebesar 26,8\%. Arah pengaruh kemampuan pemecahan masalah terhadap kemampuan berpikir kreatif siswa adalah berbanding searah, artinya jika kemampuan pemecahan pemecahan masalah siswa meningkat, maka kemampuan berpikir kreatif siswa juga meningkat. apabila dalam proses pembelajaran, guru membiasakan siswa menggunakan langkah-langkah pemecahan masalah, maka akan mengembangkan kemampuan berpikir kreatif siswa. Sebagaimana pendapat Uno, \& Mohammad (2014) bahwa pembelajaran yang memberikan kesempatan peserta didik mengeksplorasi permasalahan dapat meningkatkan kemampuan peserta didik dalam bepikir kreatif.

Nilai probabilitas hipotesis 2 sebesar $0,013<0,05$, yang berarti $\mathrm{H}_{0}$ ditolak dan $\mathrm{H}_{1}$ diterima sehingga dapat disimpulkan terdapat pengaruh pengaruh kecerdasan emosional terhadap kemampuan berpikir kreatif siswa kelas X SMK Negeri 4 Luwu. dengan kontribusi pengaruh sebesar 10,1\%. Arah pengaruh kecerdasan emosional terhadap kemampuan berpikir kreatif siswa adalah berbanding searah, artinya jika kecerdasan emosional siswa meningkat, maka kemampuan berpikir kreatif siswa juga meningkat. Sebagaimana kita ketahui bahwa emosi sebagai dasar pada diri manusia dalam menciptakan perilaku dan mengindikasikan bahwa emosi yang dimiliki oleh siswa telah baik maka perilaku tampak akan cenderung baik termasuk perilaku dalam belajar yang pada akhirnya akan menentukan prestasi belajar siswa. Untuk meningkatkan prestasi belajar siswa dalam mata pelajaran matematika, masalah dasar yang harus menjadi objek sentuhan awal yaitu proses belajar mengajar yang terjadi disekolah. Mengingat siswa juga sebagai objek dalam pendidikan maka perlu diterapkannya aspek-aspek yang ada dalam kecerdasan emosional yang meliputi kesadaran diri, pengaturan diri, empati dan keterampilan sosial dalam proses belajar mengajar dengan kata lain bahwa dalam proses belajar mengajar tidak hanya kecerdasan intelektual saja yang bersifat tidak tetap tetapi dapat berkembang sesuai dengan kesadaran individu siswa. Dengan demikian tidak dapat disangkal lagi kecerdasan emosional merupakan perkembangan yang perlu dipupuk dan disalurkan demi menunjang keberhasilan belajar bagi siswa - siswi peserta didik dimasa sekarang dan masa mendatang (Eva \& Kusrini, 2015).

Nilai probabilitas hipotesis 3 sebesar $0,000<0,05$, yang berarti $\mathrm{H}_{0}$ ditolak dan $\mathrm{H}_{1}$ diterima sehingga dapat disimpulkan terdapat pengaruh kemampuan pemecahan masalah matematika dan kecerdasan emosional terhadap kemampuan berpikir kreatif siswa kelas X SMK Negeri 4 Luwu, dengan kontribusi pengaruh sebesar 28,9\%. Arah pengaruh kemampuan pemecahan masalah dan kecerdasan emosioan terhadap kemampuan berpikir kreatif siswa adalah berbanding searah, artinya jika kemampuan pemecahan pemecahan masalah dan kecerdasan emosioanal siswa meningkat, maka kemampuan berpikir kreatif siswa juga meningkat. Kecerdasan emosional yang dimiliki siswa melalui rasa percaya diri dan kemampuan memotivasi diri membuat siswa mampu menentukan rencana penyelesaian masalah dan melaksanakan rencana penyelesaian masalah yang telah disusun. Oleh karena itu siswa yang 
terampil dalam memecahkan masalah disertai dengan kecerdasan emosional yang dimiliki mampu berpikir kreatif. Sebagaimana pendapat Uno, \& Mohammad (2014) bahwa orang-orang yang memiliki ketrampilan ini cenderung lebih produktif dan efektif dalam hal apapun yang mereka kerjakan.

\section{Kesimpulan}

Berdasarkan hasil penelitian dan pemahasan,kesimpulan dalam penelitian ini adalah 1) terdapat pengaruh kemampuan pemecahan masalah terhadap kemampuan berpikir kreatif sebesar 26,8\%. 2) terdapat pengaruh kecerdasan emosional terhadap kemampuan berpikir kreatif sebesar 10,1\%, dan 3) terdapat pengaruh secara bersama-sama kemampuan pemecahan masalah dan kecerdasan emosional terhadap kemampuan berpikir kreatif sebesar 28,9\%. Dengan demikian dapat disimpulkan bahwa semakin tinggi kecerdasan emosional yang dimiliki siswa dalam memecahkan masalah maka semakin tinggi kemampuan berpikir kreatif siswa.

\section{DAFTAR PUSTAKA}

Eva, L. M., \& Kusrini, M. (2015). Hubungan kecerdasan emosional dan berpikir kreatif terhadap prestasi belajar matematika. Formatif: Jurnal Ilmiah Pendidikan MIPA, 5(3). $3 \mathrm{~T}$

Mawaddah, S. dan Anisah, H. (2015). Kemampuan Pemecahan Masalah Matematis Siswa Pada Pembelajaran Matematika dengan Menggunakan Model Pembelajaran Generatif. Jurnal Pendidikan Matematika 3(2), 166-175.

Pehkonen, E. (1992). Using Problem-Field as a Method of Change. Mathematics Education $3(1), 3-6$

Sianipar., Valentina, K., dan Siagian, R.E.F. (2015). Peningkatan Kemampuan Pemecahan Masalah Matematika Melalui Model Pembelajaran Problem Based Learning (PBL). Prosiding Seminar Nasional Pendidikan Matematika, FTMIPA Universitas Indraprasta PGRI, 165-170.

Soeyono, Y. (2013, November). Mengasah kemampuan berpikir kritis dan kreatif siswa melalui bahan ajar matematika dengan pendekatan Open-Ended. In Seminar Nasional Matematika dan Pendidikan Matematika FMIPA UNY.

Uno, H.B., \& Mohammad, N. (2014). Belajar Dengan Pendekatan PAILKEM. Jakarta: Bumi Aksara. 